\title{
Interstitial nephritis of slaughtered pigs in the State of Mato Grosso, Brazil ${ }^{1}$
}

\author{
João X. Oliveira Filho², Daphine A.J. de Paula², Nelson Morés ${ }^{3}$, Caroline A. Pescador ${ }^{4}$, \\ Janice R. Ciacci-Zanella ${ }^{3}$, Arlei Coldebella ${ }^{3}$, Valéria Dutra ${ }^{2}$ and Luciano Nakazato ${ }^{2 *}$
}

\begin{abstract}
Oliveira Filho J.X., De Paula D.A.J., Morés N., Pescador C.A., Ciacci-Zanella J.R., Coldebella A., Dutra V. \& Nakazato L. 2012. Interstitial nephritis of slaughtered pigs inthe State of Mato Grosso, Brazil. Pesquisa Veterinária Brasileira 32(4):303-318. Laboratório de Microbiologia Veterinária e Biologia Molecular, Faculdade de Agronomia e Medicina Veterinária, Universidade Federal de Mato Grosso, Av. Fernando Corrêa da Costa 2367, Bairro Boa Esperança, Cuiabá, MT 78060-900, Brazil. E-mail: lucnak@ufmt.br

This study evaluated histological lesions in kidney samples from pigs with nephritis in two slaughterhouses in the State of Mato Grosso, Brazil. Four hundred samples were subjected to histology, anti-porcine circovirus type 2 (PCV2) immunohistochemistry (IHC), anti-Leptospira sp. immunofluorescence (IF), and polymerase chain reaction (PCR) for PCV2, porcine parvovirus (PPV), and Torque teno virus type 1 and 2 (TTV1, TTV2) detection. Histological lesions were found in $81 \%$ of the samples, and mononuclear interstitial nephritis was the most frequent lesion $(77.50 \%)$. A follicular pattern was observed in $40.97 \%$ of the interstitial nephritis lesions. PCV2, PPV, TTV1, and TTV2 were identified in the kidneys by PCR in $27.25 \%, 28.50 \%, 94 \%$, and $87.5 \%$ of the samples, respectively. Leptospira sp. was not detected through IF. Infection by PCV2 (PCR) and the presence of histological lesions $(\mathrm{P}=0.008)$ and giant cells $(\mathrm{P}=0.0016)$ were significantly associated. An association was observed between the TTV2-TTV1 co-infection $(\mathrm{P}<0.0001)$ and the risk for pathogenesis. These findings indicated that PCV2, PPV, TTV1, and TTV2 were widely distributed among pigs in the local farms and that the presence of these agents should be considered in the differential diagnosis of kidneys with interstitial nephritis in pigs.
\end{abstract}

INDEX TERMS: Pigs, interstitial nephritis, porcine circovirus type 2, torque teno virus.

RESUMO.- [Nefrite intersticial em suínos abatidos no Estado de Mato Grosso.] 0 propósito desse estudo foi avaliar as lesões histológicas observadas em rins condenados por nefrite pelo Serviço de Inspeção Federal, em dois frigoríficos de Mato Grosso, Brasil. Foram coletados 400 rins condenados por nefrite e submetidos aos exames de histologia, imuno-histoquímica (IHC) para Circovirus suíno Tipo 2 (PCV2), imunofluorescência direta (IF) para Leptospira sp. e reação em cadeia pela polimerase (PCR) para detecção

\footnotetext{
${ }^{1}$ Received on August 30, 2011.

Accepted for publication on November 28, 2011.

${ }^{2}$ Laboratório de Microbiologia Veterinária e Biologia Molecular, Faculdade de Agronomia e Medicina Veterinária (Famev), Universidade Federal de Mato Grosso (UFMT), Avenida Fernando Corrêa da Costa 2367, Bairro Boa Esperança, Cuiabá, MT 78060-900, Brazil. *Corresponding author: lucnak@ufmt.br

${ }^{3}$ Embrapa Suínos e Aves, BR153 Km 110, Vila Tamanduá, Cx. Postal 21, Concórdia, SC 89700-000, Brazil.

${ }^{4}$ Laboratório de Patologia Veterinária, Famev-UFMT, Cuiabá, MT.
}

de PCV2, Parvovirus suíno (PPV) e Torque teno vírus Tipo 1 e 2 (TTV1 e TTV2). Foram observadas lesões histológicas em $81 \%$ das amostras, sendo nefrite intersticial mononuclear a mais freqüente $(77,50 \%)$. Das lesões de nefrite intersticial encontradas, $40,97 \%$ apresentaram padrão folicular. Através da PCR foi observada ampla distribuição dos agentes (PCV2, PPV, TTV1 e TTV2) nas propriedades e municípios, com ocorrência de $27,25 \%, 28,50 \%, 94 \%$ e $87,50 \%$, respectivamente. Leptospira sp. não foi detectada através da IF. Houve associação significativa da infecção do PCV2 com presença de lesão histológica $(\mathrm{P}=0,008)$ e de células gigantes $(\mathrm{P}=0,0016)$. Também houve associação entre a co-infecção TTV2 e TTV1 $(\mathrm{P}<0,0001)$. Esses achados indicam que os vírus PCV2, PPV, TTV1 e TTV2 devem ser considerados no diagnóstico diferencial de rins com nefrite intersticial em suínos.

TERMOS DE INDEXAÇÃO: Suíno, nefrite intersticial, circovirus suíno tipo 2 , torque teno virus. 


\section{INTRODUCTION}

Mononuclear interstitial nephritis (MIN) is characterized by the presence of "white spotted areas" on the renal surface and represents the main cause for condemning kidneys in clinically healthy slaughtered pigs (Drolet et al. 2002). However, numerous etiologic agents may be involved (Drolet et al. 2002, Martinez et al. 2006).

Viral agents, such as the porcine reproductive and respiratory syndrome virus (PRRSV), porcine circovirus type 2 ( $P C V-2)$, and porcine parvovirus (PPV) might be involved in the etiology of MIN (Cooper et al. 1997, Drolet et al. 2002). Bacterial agents might also be related, for example, Leptospira interrogans, which represents an important potential risk to the health of workers in the production line (Baker et al.1989).

Considering the risks towards public health and economic losses in the pig industry resulting from decreased animal performance and organ condemnation, the association between histological lesions and etiologic agents in kidneys that were condemned by the Brazilian Federal Inspection Service (SIF), based on the presence of nephritis were evaluated in two slaughterhouses in Mato Grosso, Brazil.

\section{MATERIALS AND METHODS}

\section{Collection of samples.}

Four hundred kidneys, condemned by the SIF due to the presence of nephritis, were sampled in two slaughterhouses (FA and
FB) located in North and Southeast meso-regions of Mato Grosso-Brazil, respectively. The sample population was defined according to the method described by Thrusfield (2004) with a confidence level of $95 \%$, expected prevalence of $50 \%$, and a maximum margin of error of $5 \%$.

The average daily slaughter, from June 2003 to December 2008 in FA, and from January 2006 to December 2008 in FB, was 927 and 2,341 pigs, respectively. Random sampling was simple and proportional to the number of animals slaughtered in each slaughterhouse, totalling 152 kidneys from FA (19 kidneys/collection day) and 248 kidneys in FB (31 kidneys/collection day). All samples were obtained from 33 different farms involved in intensive production; the pigs were slaughtered at approximately the average weight of $125 \mathrm{~kg}$ and 180 days of age.

The kidneys were classified in grades from $0-3$ according to the presence of white spots on the renal surface: grade 0 (zero), normal kidney; grade 1 , mild lesions with the presence of up to five grayish-white spots; grade 2 , moderate lesions with the presence of six to 10 grayish-white spots; and grade 3 , serious lesions presenting more than 10 grayish-white spots, and/or enlarged kidneys, and/or diffused fibrosis in the capsule with irregular renal surface (Fig.1).

\section{Histological and immunohistochemical (IHC) analyses.}

Histological examination covered the areas in which the white spots were seen, from cortical to medullary portions. Samples with microscopic alterations $(n=324)$ were subjected to immunohistochemistry (IHC) for PCV2, as described by Ciacci-Zanella et al. (2006). The anti-PCV2 ORF2 region polyclonal antibody was used as the primary antibody at the dilution of 1:1500. This anti-
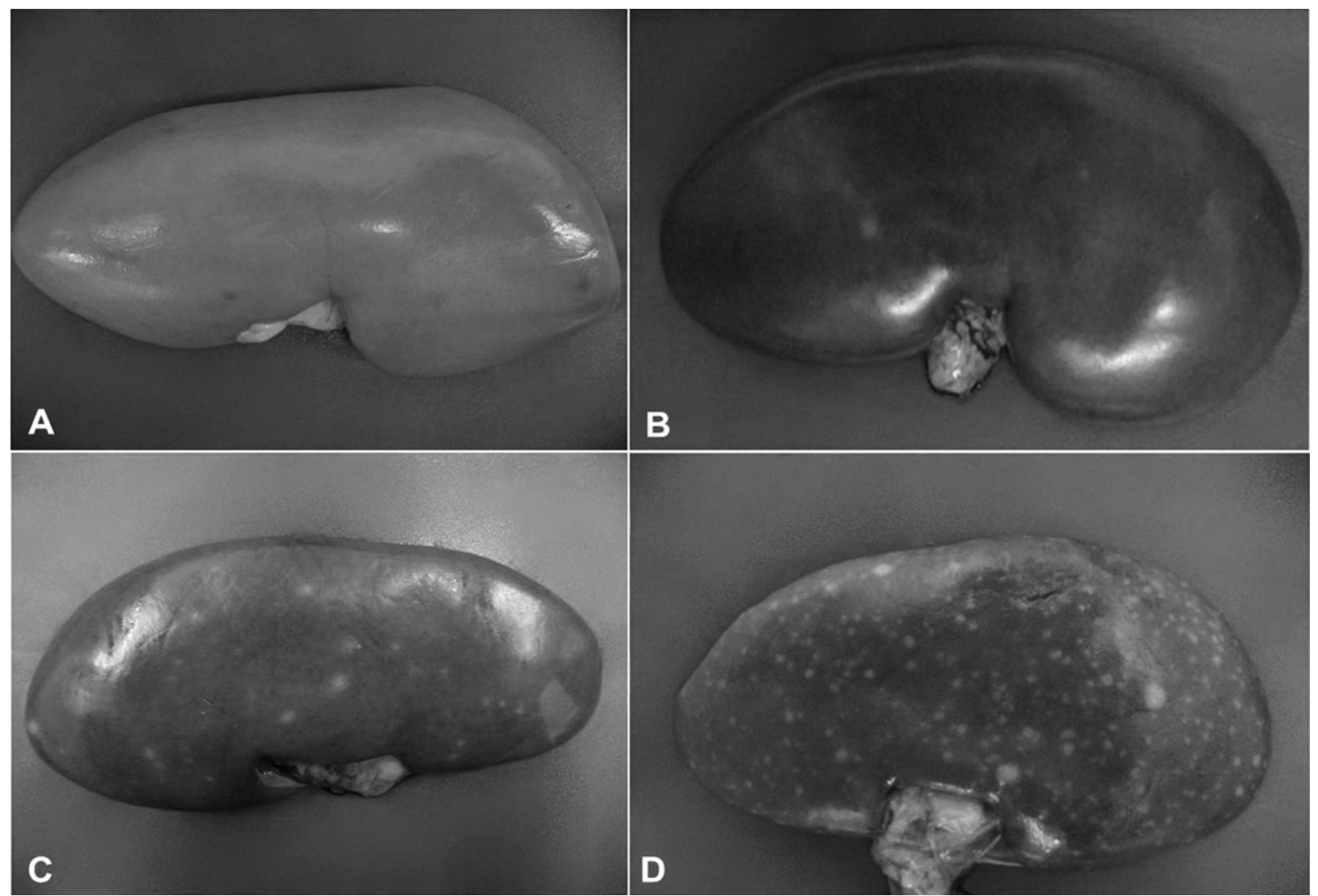

Fig.1. Degrees of macroscopic lesions in kidneys from pigs. (A) Grade 0, normal kidney. (B) Grade 1, mild lesions with the presence of up to five grayish-white spots. (C) Grade 2, moderate lesions with the presence of six to twenty grayish-white spots. (D) Grade 3, severe lesions presenting more than 20 grayish-white spots. 
body was produced in rabbits (prepared at the Iowa State University and kindly provided by Professor David Driemeier, UFRGS). Lymph node samples from specific pathogen free animals (SPF) served as negative controls. Lymph node samples from PMWS affected pigs (confirmed by nested-PCR) were positive controls.

\section{Immunofluorescence (IF) for Leptospira sp.}

Imprints, taken during the collection of samples were subsequently fixed in acetone p.a. for IF according to Ellis et al. (1982). The LEP-FAC (NVSL) polyclonal antibody, prepared in rabbits and conjugated with fluorescein isothiocyanate, was used at the dilution of 1:2500. Smears of pure cultures of L. interrogans serovar Pomona fixed in heat and acetone p.a. were positive controls.

\section{Polymerase Chain Reaction (PCR).}

Genomic DNA was extracted from $100 \mathrm{mg}$ of kidney tissue after Proteinase K digestion, as described by Sambrook \& Russell (2001). Detection of viral DNA through PCR followed the methods described by Fenaux et al. (2000) (PCV2) and Kim \& Chae (2004) (PPV), and through Nested-PCR described by Kekarainen et al. (2006) (TTV2 and TTV1). Samples with proven identity through genome sequencing were the positive controls and ultra pure water samples were the negative controls. Amplified PCR products were separated by agarose gel electrophoresis (1.0\%), stained with ethidium bromide, and analyzed in an UV transilluminator.

\section{Statistical analysis.}

Data related to the presence of agents and histological lesions were statistically analyzed. Initially, a descriptive analysis of the data by frequency tables was executed. The association between variables was calculated using the Yate's corrected Chi-square test $(\chi 2)$ and the Fisher's exact test. Associations with 5\% probability level were considered significant. The odds ratios (OR) were calculated with a confidence interval (IC) of $95 \%$ for the significant associations. These analyses were performed in the GraphPad InStat software for Windows.

\section{RESULTS}

\section{Pathological evaluation}

The samples classified as grade 3 presented the higher frequency of nephritis $(190 / 400-47.50 \%)$ in the macroscopic evaluations, followed by grade $1(128 / 400-32 \%)$ and grade 2 samples $(82 / 400-20.50 \%)$. In the histological evaluations, $19 \%(76 / 400)$ of the kidneys showed no nephritis changes and were therefore normal. There was no association between the macroscopic degree of lesions and the presence of microscopic lesions $(\mathrm{P}=0.1175)$.

MIN showed the highest frequency $(310 / 400-77.50 \%)$ among the samples with histological lesions $(324 / 400$ - 81\%) (Table 1). Among these, 127/310 (40.97\%) presented a follicular pattern, and the inflammatory response occurred in the form of lymphoid follicles (Fig.2). Other inflammatory changes such as giant cells $(13 / 400$ - $3.25 \%)$, glomerulitis (7/400 - 1.75\%), and membranoproliferative glomerulonephritis $(5 / 400-1.25 \%)$ were also observed.

Histological lesions were mostly observed in the cortical region $(312 / 400-78 \%)$, followed by those presented in the medullary region $(9 / 400-.25 \%)$ and renal pelvis $(3 / 400-0.75 \%)$. Kidney lesions were predominantly of multifocal distribution (247/400 - 61.75\%).
Table 1. Histological lesions in porcine kidneys condemned by the Federal Inspection Service, as presenting nephritis $(n=400)$, in the state of Mato Grosso, Brazil, from March to April 2009

\begin{tabular}{lcc}
\hline \multicolumn{1}{c}{ Histological alteration } & \multicolumn{2}{c}{ Presence } \\
\cline { 2 - 3 } & $(\mathrm{n})$ & $(\%)$ \\
\hline Without alteration & 76 & $19.00 \%$ \\
With alteration & 324 & 81.00 \\
MIN $^{\text {a }}$ & 183 & 45.75 \\
MIN $^{\mathrm{a}}$ with follicular pattern & 127 & 31.75 \\
Interstitial fibrosis $_{\text {Presence of protein inside renal tubules }}$ & 27 & 6.75 \\
Presence of giant cells & 22 & 5.50 \\
Tubular degeneration & 13 & 3.25 \\
Glomerulitis & 9 & 2.25 \\
Membranoproliferative glomerulonephritis & 7 & 1.75 \\
Eosinophilic infiltrate & 5 & 1.25 \\
Infarct & 3 & 0.75 \\
\end{tabular}

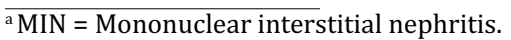

\section{Aetiological findings}

Viral antigens and nucleic acids from PCV2, PPV, TTV1, and TTV2 were detected in 109/400 (27.25\%), 114/400 (28.50\%), 376/400 (94\%), and 350/400 (87.5\%) in the analyzed kidneys, respectively. Positive samples for Leptospira sp. were not detected. PCV2 and PPV positive samples were identified in 23/33 (66.67\%) and 27/33 (81.82\%) in the samples from the farms and in $11 / 13(84.62 \%)$ and $12 / 13(92.34 \%)$ in the samples from the municipalities, respectively. TTV1 and TTV2 positive samples were detected in 33/33 (100\%) in the samples from the farms and municipalities (Table 2).

Table 2. Geographic distribution of Porcine Circovirus Type 2 (PCV2), swine Parvovirus (PPV), and Torque teno virus Type 1 and 2 (TTV1 and TTV2) in pig kidneys condemned by the Federal Inspection Service, as presenting nephritis in Mato Grosso, Brazil

\begin{tabular}{llccccc}
\hline Mesoregion & Municipalities & Properties & \multicolumn{3}{c}{ Number of positive farms } \\
\cline { 3 - 7 } & & & PCV2 & PPV & TTV1 & TTV2 \\
\hline \multirow{2}{*}{ North } & Diamantino & 01 & 1 & 1 & 1 & 1 \\
& Lucas do Rio Verde & 04 & 3 & 4 & 4 & 4 \\
& Nova Mutum & 04 & 1 & 3 & 4 & 4 \\
& Novo Horizonte & 01 & 0 & 1 & 1 & 1 \\
& Santa Rita do Trivelato & 01 & 1 & 1 & 1 & 1 \\
& Sorriso & 05 & 4 & 3 & 5 & 5 \\
& Tapurah & 09 & 6 & 7 & 9 & 9 \\
& Vera & 01 & 1 & 1 & 1 & 1 \\
& Campo Verde & 02 & 2 & 2 & 2 & 2 \\
& Itiquira & 01 & 1 & 1 & 1 & 1 \\
& Pedra Preta & 01 & 1 & 1 & 1 & 1 \\
& Poxorén & 02 & 2 & 2 & 2 & 2 \\
& Rondonópolis & 01 & 0 & 0 & 1 & 1 \\
& N & 33 & 23 & 27 & 33 & 33 \\
& \% & 100 & 66.67 & 81.82 & 100 & 100
\end{tabular}

PCV2 was detected by PCR in 98/324 (30.25\%) and by IHC in $41 / 324(12.65 \%)$ in the samples with histological changes. These results were classified in ranges with a cross sign (+ indicating a weak positive reaction). The viral antigen was detected in the renal interstitium and tubules (Fig.2), in the corticomedullary regions, in glomeruli, giant cells, and in the cytoplasm of histiocytes. A positive significant association was observed between the IHC and PCR results $(\mathrm{P}<0.0001)$. The probability of kidney samples 


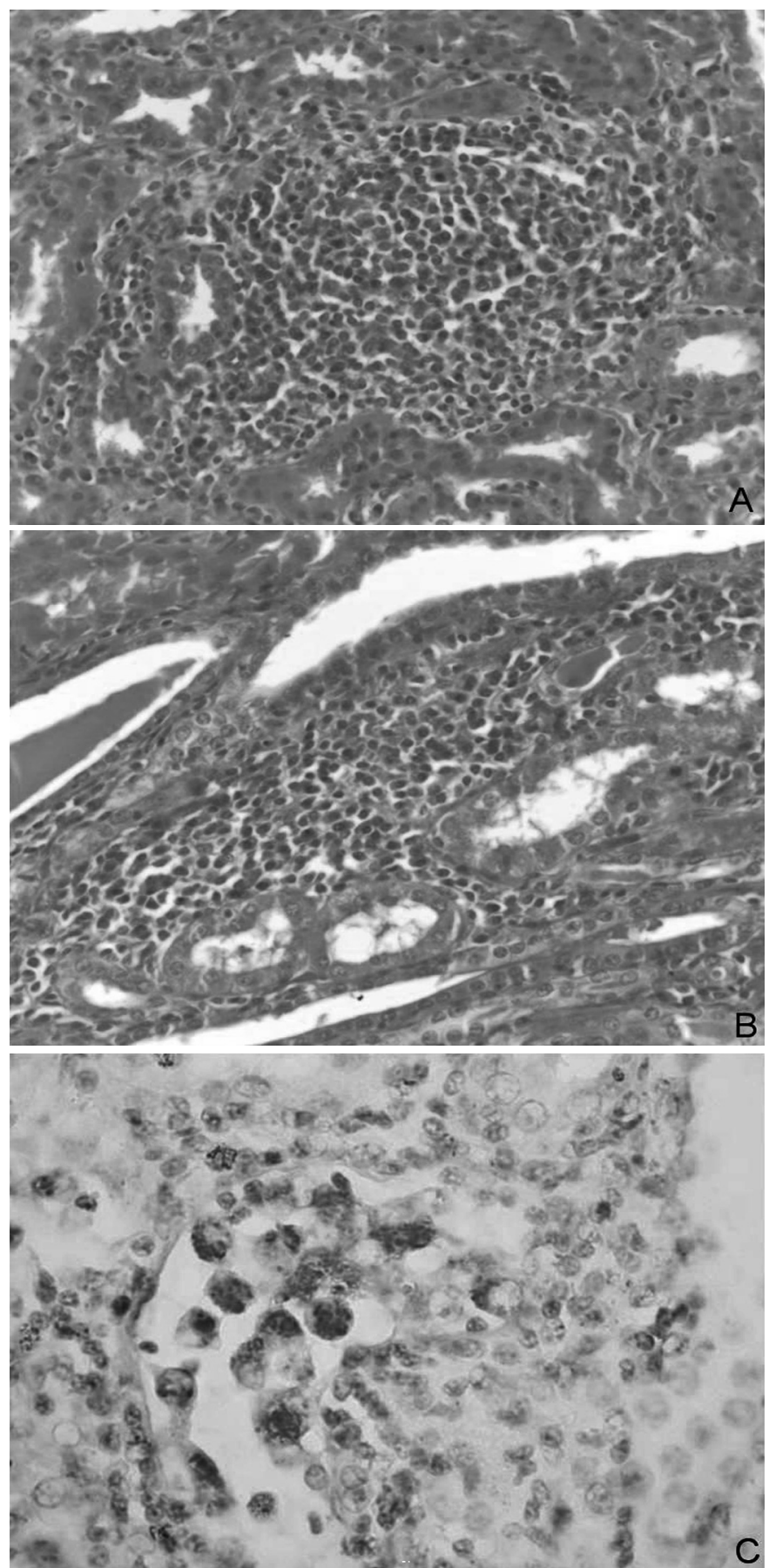

Fig.2. (A) Mononuclear nephritis with moderate focal follicular pattern in pig. HE, obj.40x. (B) Moderate focal mononuclear interstitial nephritis in pig. HE, obj.40x. (C) Positive PCV-2 immunolabeling within the renal tubule. Avidin-streptavidin-peroxidase, obj.40x.

with histological lesions to be positive for PCV2 by IHC was 6.5 times higher when these samples were also positive for PCV2 by PCR (Table 3).

A significant association was also observed between the presence of PCV2, detected by PCR in samples with microscopic lesions $(\mathrm{P}=0.008)$, and the presence of giant cells $(\mathrm{P}=0.0016)$. The probabilities of kidney samples to present histological lesions and giant cells were 2.57 and 6.45 times higher when they were positive for PCV2 by PCR, respectively.
Table 3. Association between the presence of PCV2 detected by PCR and the presence of PCV2 detected by immunohistochemistry and histological changes in porcine kidneys condemned by the Federal Inspection Service as presenting nephritis in two slaughterhouses in Mato Grosso, Brazil

\begin{tabular}{|c|c|c|c|c|c|c|}
\hline \multirow[t]{2}{*}{ Variable } & \multicolumn{2}{|c|}{ PCV2 - PCR } & \multirow[t]{2}{*}{$\mathrm{P}$} & \multirow[t]{2}{*}{$x^{2}$} & \multirow[t]{2}{*}{$\mathrm{OR}^{\mathrm{b}}$} & \multirow[t]{2}{*}{$\mathrm{CI}^{\mathrm{c}} 95 \%$} \\
\hline & Samples & Positive (\%) & & & & \\
\hline \multicolumn{7}{|c|}{ PCV2- immunohistochemistry } \\
\hline Negative & 283 & $70(24.73 \%)$ & $<0.0001$ & 30.17 & 6.5 & $3.2-13.3$ \\
\hline Positive & 41 & $28(68.29 \%)$ & & & & \\
\hline \multicolumn{7}{|c|}{ Histological lesion } \\
\hline Negative & 76 & $11(14.5 \%)$ & 0.008 & 6.95 & 2.56 & $1.29-5.0$ \\
\hline Positive & 324 & $98(30.35 \%)$ & & & & \\
\hline \multicolumn{7}{|c|}{ Presence of giant cells } \\
\hline Negative & 387 & $100(25.84 \%)$ & 0.0016 & $10.38^{\mathrm{a}}$ & 6.45 & $1.94-21.43$ \\
\hline Positive & 13 & $9(69.23 \%)$ & & & & \\
\hline
\end{tabular}

${ }^{\text {a }}$ Fisher's Exact Test; ${ }^{\mathrm{b}} \mathrm{OR}=$ Odds Ratio; ${ }^{\mathrm{c}} \mathrm{CI}=$ confidence interval of $95 \%$.

Significant associations were observed between the presence of TTV1 and the presence of glomerulitis $(\mathrm{P}=0.027)$ and tubular degeneration $(\mathrm{P}=0.005)$; similarly, between the presence of TTV2 and the presence of protein in the renal tubules $(\mathrm{P}=0.012)$ and tubular degeneration $(\mathrm{P}=0.0002)$. Co-infection with TTV1 and TTV2 was observed in $84.25 \%$ $(337 / 400)$ of the samples showing significant association $(\mathrm{P}<0.0001)$. In the studied samples, the probability of TTV2 infection was 7.31 times greater when the animal was also infected by TTV1 ( $\chi^{2}=22.7$; CI 95\%: 3.0-17.4).

\section{DISCUSSION}

The present study contributes to the pathological and aetiological characterization of nephritis lesions identified and condemned by SIF in healthy pigs from slaughterhouses. The number of healthy kidneys condemned as presenting nephritis, but that were considered normal in the histological evaluation was significant (19\%). The absence of association between the macroscopic degree of lesions with the presence of microscopic lesions, and the frequency of kidneys classified as presenting nephritis without histological lesions explain the difficulty in distinguishing nephritis from vascular disorders, which may cause alterations in the colour of the organ's surface and thus, confuse the evaluator in the slaughter line.

Different results were obtained by Martínez et al. (2006) in a study with kidneys from pigs from a slaughter in eastern Spain. They reported that $6.9 \%$ of the kidneys considered normal in the histological analysis were classified as presenting nephritis in the macroscopic assessment resulting in significant association between nephritic macroscopic lesions and the presence of microscopic lesions $(p<0.005)$. These results indicate the need to enhance the technical criteria for assessing such macroscopic evaluations, as well as the training and monitoring of professionals responsible for the inspection. Furthermore, the results supported the importance in conducting pathological studies in order to characterize lesions observed in slaughtered animals.

Mononuclear interstitial nephritis was the main microscopic lesion detected in this study (77.50\%), 40.97\% of which presented a follicular lesion pattern. Similar results 
were previously observed and the reported prevalence ranges from 61.87 to $100 \%$ (Neves 1985, Drolet et al. 2002, Martínez et al. 2006). PCV2 infection has been associated with MIN (Segalés et al. 2004) and lymphohistiocytic infiltrate has been linked to the presence of giant cells (Segalés \& Domingo 2002). Similarly, in the present study, PCV2 infection was associated with the presence of giant cells $(\mathrm{P}=0.0016 ; \mathrm{OR}=2.56)$.

Leptospira sp. was not detected through bacterial isolation in the analyzed samples; Drolet et al. (2002) report similar results. This may be a result of infection control programs in the farms through mass vaccinations, better condition of hygiene in the premises, and the use of antibiotics (Ribotta et al. 1999). Martínez et al. (2006) observed only two positive samples for Leptospira sp. by IF in a similar study. However, in some studies executed in the 1980s, researchers showed an association between the presence of this bacterium and the occurrence of MIN using serology, immunofluorescence techniques, and culture of pig samples (Grégoire et al. 1987, Baker et al. 1989). The results presented here suggested that a significant improvement in the control of this important zoonosis in swine culture has taken place in the recent decades.

This study indicated that the analyzed agents were widely distributed in Mato Grosso (Brazil). It is important to emphasize that the number of samples infected with PCV2 may be underestimated because the agent may no longer be present in chronic lesions (Maxie \& Newman 2007). Furthermore, kidneys have not been the targeted organs for PCV2 infection (Segalés \& Domingo 2002), except in porcine dermatitis and nephropathy syndrome cases (Choi et al. 2002).

Even with the lower sensitivity of the IHC technique to detect PCV2 in comparison with PCR, IHC is useful to localize the agent in the tissue and demonstrate the pathogenic role of PCV2 in the occurrence of porcine nephritis. PCV2 was observed in the interstitium, renal tubules, glomeruli, in the giant cells, and in the cytoplasm of histiocytes. These results support the assumption that PCV2 can replicate in the functional structures of the kidneys (tubules and nephrons) as it has also been reported by Sarli et al. (2008). Hence, PCV2 might be involved in the occurrence of MIN.

The presence of PPV in the samples was relevant; however, no significant association was observed between other agents and the presence of histological lesions. This result is contrary to the results reported by Drolet et al. (2002) who demonstrated significant association between interstitial nephritis lesions and the presence of PCV2 $(\mathrm{P}=0.0074)$ and $\mathrm{PPV}(\mathrm{P}<0.0001)$ with an $\mathrm{OR}=3.4$ and 7.5 , respectively. These authors also observed that the OR increased to $22.7(\mathrm{P}<0.0001)$ when there was co-infection with both viruses. Other studies reported association between PCV2 and PPV and the development of diseases such as post weaning multisystemic wasting syndrome in pigs (PMWS), renal lesions, and reproductive failures (Allan et al. 1999, Kim \& Chae 2004, Fernandes et al. 2006, Pescador et al. 2007).

The high occurrence of TTV infection (20-73\%) observed in these pigs agrees with results previously reported
(Leary et al. 1999, Bigarré et al. 2005). Such a high prevalence can be explained by the containment conditions that facilitates transmission (Deng et al. 2000, Gerner et al. 2000, Martínez-Guinó et al. 2009) and the ubiquitous characteristic of TTV.

Significant associations were observed between infection by TTV1 and the presence of glomerulitis and tubular degeneration, and between infection by TTV2 and the presence of protein in renal tubules and tubular degeneration. These results are not biologically plausible because infections by TTV1 and 2 were considered as a protective factor in the occurrence of these lesions in the odds ratio analyses. In fact, in this study, the high occurrence of TTV was associated with a low occurrence of these lesions.

Associations between TTV and the other analyzed agents were not observed. It was observed that the infection by a genogroup of TTV represented a risk factor for the occurrence of co-infection with another genogroup $(\mathrm{OR}=7.31)$ and it might be associated with the pathogenicity of one of the agents. However, Kekarainen et al. (2006) compared the TTV infection in pigs with and without PMWS, and observed association $(\mathrm{P}<0.05)$ between TTV infection and the presence of PMWS. These authors also demonstrated associations between TTV2 and the presence of PMWS and between TTV1 and pigs with no syndrome. The TTV viral load in pigs, which was not analyzed in the present study, can be another factor related to the occurrence of lesions because of the ability of TTV to modulate the immune system through the inhibition of INF- $\alpha$; a greater effect was observed with 1000 ng of TTV DNA when compared with 500ng (Martínez-Guinó et al. 2010).

The present study demonstrated that a significant number of kidneys, considered as presenting nephritis, did not present histological lesions (19\%). In addition, this study demonstrated that several histological changes observed in the kidneys with MIN were associated with the infection of viral agents such as the PCV2, PPV, TTV1, and TTV2. Although Leptospira $s p$. was not detected in the analyzed samples, constant monitoring is important because of its zoonotic potential and the health problems that can result from this infection.

Acknowledgements.- To the slaughterhouses' owners/managers and to SIF-MT, for enabling the execution of this study, and to CAPES for the scholarship granted. The authors are also thankful to the technical assistance in the immunohistochemistry analyses provided by Kelen R.A. Baldi, Animal Health Diagnostic Center (CEDISA), Brazil, and to Neide L. Simon and Giseli Ritterbusch for the technical assistance in the Torque Teno Virus PCR detection, Embrapa Swine and Poultry Research Center (CNPSA), Concórdia, SC.

\section{REFERENCES}

Allan G., Kennedy S., Mcneilly F., Foster J.C., Ellis J., Krakowka S., Meehan B.M. \& Adair B.M. 1999. Experimental reproduction of severe wasting disease by co-infection of pigs with porcine circovirus and porcine parvovirus. J. Comp. Pathol. 121:1-11.

Baker T., McEwen S., Prescott J. \& Meek A. 1989. The prevalence of leptospirosis and its association with multifocal interstitial nephritis in swine at slaughter. Can. J. Vet. Res. 53:290-294.

Bigarré L., Beven V., De Boisséson C., Grasland B., Rose N., Biagini P. \& Jestin A. 2005. Pig anelloviruses are highly prevalent in swine herds in France. J. Gen. Virol. 86:631-635. 
Choi C., Kim J., Kang I. \& Chae C. 2002. Concurrent outbreak of PMWS and PDNS in a herd of pigs in Korea. Vet. Rec. 151:484-485.

Ciacci-Zanella J.R., Morés N., Simon N.L., Oliveira S.R. \& Gava D. 2006. Identificação do circovírus suíno tipo 2 por reação em cadeia da polimerase e por imunoistoquímica em tecidos suínos arquivados desde 1988 no Brasil. Ciência Rural 36(5):1480-1485.

Cooper V., Hesse R. \& Doster A. 1997. Renal lesions associated with experimental porcine reproductive and respiratory syndrome virus (PRRSV) infection. J. Vet. Diagn. Invest. 9:198-201.

Deng X., Terunuma H., Handema R., Sakamoto M., Kitamura T., Ito M. \& Akahane Y. 2000. Higher prevalence and viral load of TT virus in saliva than in the corresponding serum: Another possible transmission route and replication site of TT virus. J. Med. Virol. 62:531-537.

Drolet R., D’Allaire S., Larochelle R., Magar R., Ribotta M. \& Higgins R. 2002. Infectious agents identified in pigs with multifocal interstitial nephritis at slaughter. Vet. Rec. 150:139-143.

Ellis W., O’Brien J., Neill S., Ferguson H. \& Hanna J. 1982. Bovine leptospirosis: microbiological and serological findings in aborted fetuses. Vet. Rec. 110:147-150.

Fenaux M., Halbur P., Gill M., Toth T. \& Meng X. 2000. Genetic characterization of type 2 porcine circovirus (PCV-2) from pigs with postweaning multisystemic wasting syndrome in different geographic regions of North America and development of a differential PCR-restriction fragment length polymorphism ssay to detect and differentiate between infections with PCV-1 and PCV-2. J. Clin. Microbiol. 38:2494-2503.

Fernandes L.T., Ciacci-Zanella J.R., Sobestiansky J., Schiochet M.F. \& Trombetta C. 2006. Coinfecção experimental de circovírus suíno tipo 2 isolado no Brasil e parvovírus suíno em suínos SPF. Arq. Bras. Med. Vet. Zootec. 58:1-8.

Gerner P., Oettinger R., Gerner W., Falbrede J. \& Wirth S. 2000. Mother-to-infant transmission of TT virus: prevalence, extent and mechanism of vertical transmission. Pediatr. Infect. Dis. J. 19:1074-1077.

Grégoire N., Higgins R. \& Robinson Y. 1987. Isolation of leptospires from nephritic kidneys of beef cattle at slaughter. Am. J. Vet. Res. 48:370371.

Kekarainen T., Sibila M. \& Segalés J. 2006. Prevalence of swine Torque teno virus in post-weaning multisystemic wasting syndrome (PMWS)-affected and non-PMWS-affected pigs in Spain. J. Gen. Virol. 87:833-837.

Kim J. \& Chae C. 2004. A comparison of virus isolation, polymerase chain reaction, immunohistochemistry, and in situ hybridization for the de- tection of porcine circovirus 2 and porcine parvovirus in experimentally and naturally coinfected pigs. J. Vet. Diagn. Invest. 16:45-50.

Leary T., Erker J., Chalmers M., Desai S., Mushahwar I. 1999. Improved detection systems for TT virus reveal high prevalence in humans, non-human primates and farm animals. J. Gen. Virol. 80:2115-2120.

Martinez J., Segalés J., Aduriz G., Atxaerandio R., Jaro P., Ortega J., Peris B. \& Corpa J.M. 2006. Pathological and aetiological studies of multifocal interstitial nephritis in wasted pigs at slaughter. Res. Vet. Sci. 81:92-98.

Martínez-Guinó L., Kekarainen T. \& Segalés J. 2009. Evidence of Torque teno virus (TTV) vertical transmission in swine. Theriogenology 71:1390-1395.

Martínez-Guinó L., Mccullough K.C., Summerfield A., Segalés J. \& Kekaraine T. 2010. Impact of Torque teno virus (TTV) on porcine dendritic cell function and activity. Proc. $21^{\text {st }}$ International Pig Veterinary Society Congress, Vancouver, Canada, p.879.

Maxie M.G. \& Newman S.J. 2007. Urinary System, p.425-522. In: Juub, K.V.F., Kennedy, P.C. \& Palmer, N. (Eds), Patology of Domestic Animals. Vol 2. $5^{\text {th }}$ ed. Saunders Elsevier, Philadelphia.

Neves D.S. 1985. Patologia Renal de Suínos Abatidos. Minas Gerais, Brasil. Dissertation of Master's Degree, Universidade Federal de Minas Gerais, Belo Horizonte. 69p.

Pescador C.A., Bandarra P.M., Castro L.A., Antoniassi N.A.B., Ravazzolo A.P., Sonne L., Cruz C.E.F \& Driemeier D. 2007. Co-infection by porcine circovirus type 2 and porcine parvovirus in aborted fetuses and stillborn piglets in southern Brazil. Pesq. Vet. Bras. 27:425-429.

Ribotta M., Higgins R. \& Perron D. 1999. Swine leptospirosis: low risk of exposure for humans?. Can. Vet. J. 40:809-810.

Sarli G., Mandrioli L., Panarese S., Brunetti B., Segalés J., Domínguez J. \& Marcato P.S. 2008. Characterization of interstitial nephritis in pigs with naturally occurring postweaning multisystemic wasting syndrome. Vet. Pathol. 45:12-18.

Sambrook J. \& Russell D.W. 2001. Molecular cloning: a laboratory manual. $2^{\text {nd }}$ ed. Ed Press CsHL, New York, p.2.56-2.60.

Segalés J. \& Domingo M. 2002. Postweaning multisystemic wasting syndrome (PMWS) in pigs: a review. Vet. Quart. 24:109-124.

Segalés J., Rosell C. \& Domingo M. 2004. Pathological findings associated with naturally acquired porcine circovirus type 2 associated disease. Vet. Microbiol. 98:137-149.

Thrusfield M. 2004. Epidemiologia Veterinária. $2^{\text {nd }}$ ed. Roca, São Paulo. 572p. 